\title{
Water4Cities: An ICT Platform Enabling Holistic Surface Water and Groundwater Management for Sustainable Cities ${ }^{\dagger}$
}

\author{
Stamatia Rizou 1,*, Klemen Kenda 2, Dimitris Kofinas ${ }^{3}$, Nikos Mellios 3,4, Petra Pergar 5 , \\ Panagiotis D. Ritsos ${ }^{6}$, John Vardakas ${ }^{7}$, Kostas Kalaboukas ${ }^{1}$, Chrysi Laspidou ${ }^{3}$, \\ Matej Senožetnik ${ }^{2}$ and Alexandra Spyropoulou ${ }^{3}$ \\ 1 Singular Logic S.A., 14564 Athens, Greece; kkalaboukas@singularlogic.eu \\ 2 Artificial Intelligence Laboratory, Jozef Stefan Institute, Ljubljana 1000, Slovenia; \\ klemen.kenda@ijs.si (K.K.); matej.senozetnik@ijs.si (M.S.) \\ 3 Civil Engineering Department, University of Thessaly, 38334 Volos, Greece; dkofinas@civ.uth.gr (D.K.); \\ nmellios@uth.gr (N.M.); laspidou@uth.gr (C.L.); aespyropoulou@gmail.com (A.S.) \\ 4 Municipal Enterprise for Water Supply and Sewage Treatment of Skiathos, 37002 Skiathos, Greece; \\ deyask@otenet.gr \\ 5 Ljubljanski Urbanistični zavod d.d., Ljubljana SI-1000, Slovenja; Petra.Pergar@luz.si \\ 6 School of Computer Science and Electronic Engineering, Bangor University, Bangor LL57 1UT, UK; \\ p.ritsos@bangor.ac.uk \\ 7 Iquadrat Informatica, 08009 Barcelona, Spain; jvardakas@iquadrat.com \\ * Correspondence: srizou@singularlogic.eu; Tel: +30-2106267418 \\ + Presented at the 3rd EWaS International Conference on "Insights on the Water-Energy-Food Nexus", \\ Lefkada Island, Greece, 27-30 June 2018.
}

Published: 7 August 2018

\begin{abstract}
To enable effective decision-making at the entire city level, both surface water and groundwater should be viewed as part of the extended urban water ecosystem with its spatiotemporal availability, quantity, quality and competing uses being taken into account. The Water4Cities project aims to build an ICT solution for the monitoring, visualization and analysis of urban water at a holistic urban setting to provide added-value decision support services to multiple water stakeholders. This paper presents the main stakeholders identified, the overall approach and the target use cases, where Water4Cities platform will be tested and validated.
\end{abstract}

Keywords: urban water management; sensors; ICT; analytics; sustainability; water stakeholders; system architecture

\section{Introduction}

Urban water management becomes progressively more challenging in the view of population growth, emerging climate change stress on water resources [1], decreasing resilience of aging infrastructure, such as water distribution networks (WDNs) and tanks, and increasing complexity of water management systems [2]. Recent review on Water Distribution Systems (WDSs) optimization schemes [3] highlights the complexity of optimizing a WDN and reveals the major role of technological evolution in facilitating smart water solutions through the past three decades. A smart water solution would involve and integrate real-time or near-real-time remote sensing and control, forecasting algorithms and platforms to shape up a Decision Support System (DSS) which aims at sustainable resources use [4]. Despite ongoing research, there is great room for progress in linking water sources-surface and groundwater-to urban water systems as part of a holistic urban water management approach. 
Rapid urbanization, intensified agriculture and industry combined with water scarcity and climate change pressures that include long drought periods or extreme storm water events and diminishing fresh water supplies [5], set water quantity and quality monitoring as an imperative component of an efficient urban water management scheme, resulting in the wider adoption of monitoring technologies (smart meters, sensors etc.) by water stakeholders [4,6,7]. Worldwide, policy instruments, such as the EC Water Framework Directive [8] and the US Environmental Protection Agency (EPA) Water Management Plans and Best Practices [9] are applying pressure to authorities of all levels to actually implement such innovative solutions. However, the deployment of advanced high-quality real-time monitoring activities in urban settings is not yet achieved due to several reasons including: (i) difficulties in collecting precise and robust monitoring data due to sensor technologies limitations, such as limited battery lifetime and limited transmission range especially for groundwater monitoring [10,11]; (ii) standardization issues that prohibit interoperability [12,13] and (iii) use of simple data mining and data visualization algorithms that do not fully exploit the value of data collected.

The Water4Cities project [14] will rely on sensor technologies, data and visual analytics to enable localization, modelling, forecasting and visualization of urban water resources (both surface water and groundwater), as well as urban water infrastructure, at a holistic urban setting providing services to multiple water stakeholders. In this line, the Water4Cities project aims to develop an Information and Communications Technology (ICT) platform that will enable water utilities, authorities and other relevant stakeholders to (a) monitor in real-time critical urban water resources parameters; (b) support their decisions for optimal urban water management of minimal environmental impact and (c) involve policy makers, corporations and public to provide support for sound and balanced decision-making.

On top of the technical limitations, there is currently a lack from the methodological viewpoint with respect to treating the urban water ecosystem in a holistic manner, which depicts the interrelationships between different components such as surface water, groundwater, wastewater, water reuse potential, the water-energy nexus, as well as conflicting policies and/or subsidies that lead to uncertain results. The Water4Cities project will contribute to a sustainable management of urban water by relying on three main innovation pillars: (i) the design of a holistic integrated methodology for urban surface water and groundwater monitoring and management; (ii) the construction of a beyond the state-of-the-art data collection mechanism for urban water monitoring; (iii) the enablement of real-time spatiotemporal visualization of water resources for sustainable urban water management.

In this paper, we investigate different stakeholders' involvement in the urban water ecosystem, and we present the high-level architecture of the Water4Cities platform, which provides a unique ICT-based solution as a response to their needs. In Section 2, we present the high-level system architecture, which includes a robust, energy efficient monitoring infrastructure and appropriate data mining and visualization tools. In this line, we describe the Water4Cities services offered to different stakeholders, e.g., the optimization of water management decisions, the assessment of existing synergies between energy and water use, and the impact of climate change on available water resources. In Section 3, we identify the several Water4Cities actors (utilities, regional/national authorities, policy makers, citizens etc.), their expected interest in Water4Cities and potential conflicts among stakeholders. Finally, in Section 4, we provide an overview of the target use cases considered in the context of the Water4Cities project and we conclude the paper in Section 5.

\section{Materials and Methods}

The overall vision of the Water4Cities project is to deliver optimized urban monitoring and decision support services through advanced visualization tools. The central concept of Water4Cities project is to provide water managers the appropriate tools that will enable them to assess the implications of their decisions, such as groundwater over-exploitation, trade-off between energy and water use, introduction of different land uses, the effects of climate change on available water resources, etc. Figure 1 shows the high-level architecture of the envisioned Water4Cities system. The 
architecture follows a standard 3-tier model, comprising three layers (i.e., Data layer, Platform Layer and Application Layer):

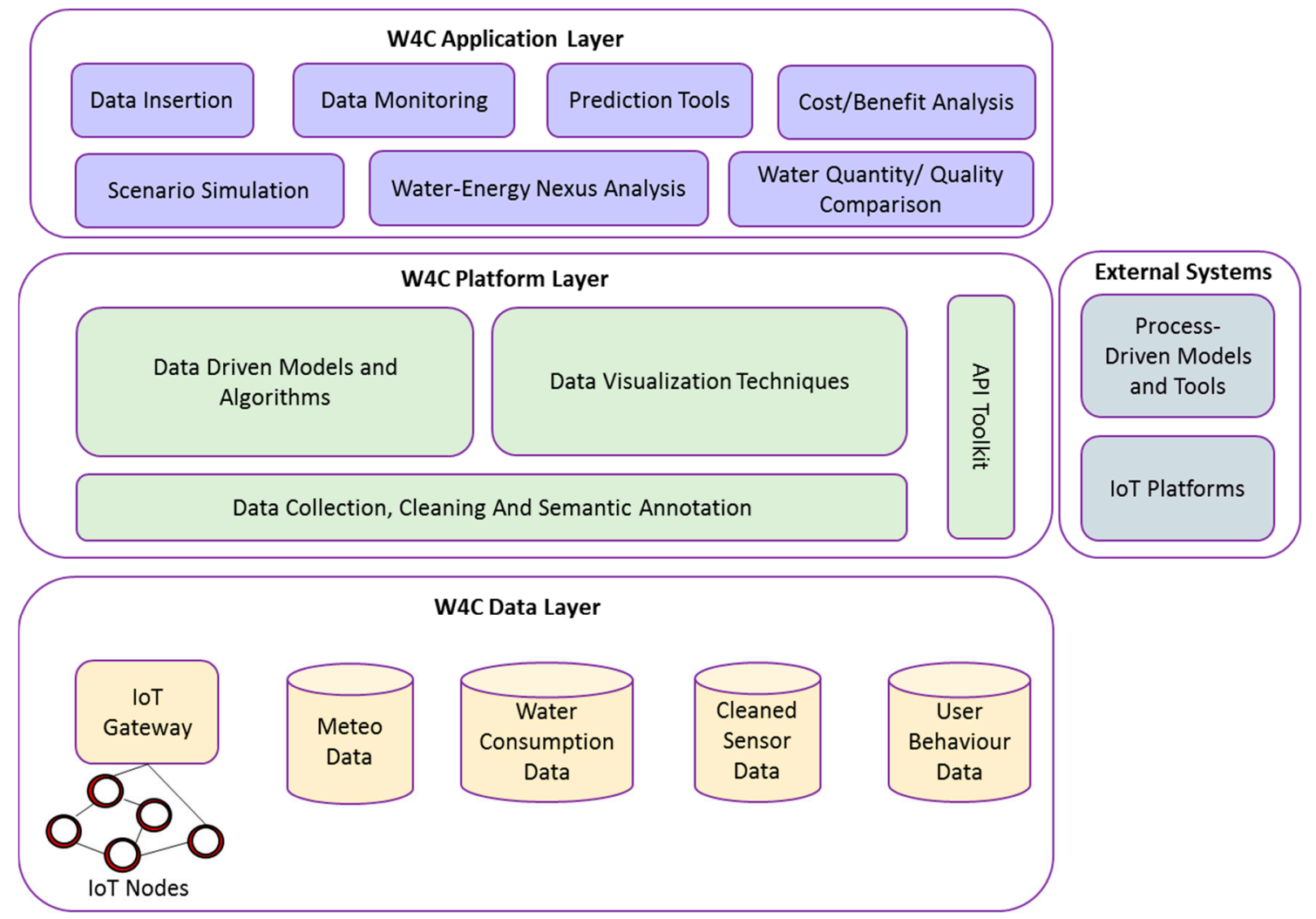

Figure 1. High Level Water4Cities System Architecture.

- Data Layer refers to the different data sources, including real-time sensor data collected in an efficient manner through the IoT Gateway. Water4Cities will rely on energy efficient communication protocols to allow data collection even in hard-to-reach places in the case of groundwater monitoring. Beyond, sensor data, which will constitute the main data source for the project, Water4Cities will allow also the integration of existing data, such as water consumption data, meteorological data etc.

- Platform Layer contains the core components of the Water4Cities system, enabling the processing of data to extract useful knowledge. Water4Cities will focus on the development of data-driven models and tools to analyse sensor data and historical or static data to assist water management decisions. Initially, data collected will be cleaned (from potential outliers) and be semantically annotated. The outputs of the data-driven analysis will be fed to appropriate data visualization techniques to facilitate data analysis and increase user engagement. In addition, the platform will provide an API toolkit enabling the exchange of information with third-party tools (typically process-driven tools widely used in water modelling).

- Application Layer consists of a number of services provided through a unified GUI by the Water4Cities platform. This layer may include the following services: (i) Data Insertion enabling users to contribute their data in the platform; ii) Data monitoring and visualization in different formats; (iii) Prediction tools for the prediction of water quantity supply and demand; (iv) CostBenefit analysis for interventions (e.g., planning for green infrastructure measures); (v) Scenario simulation (e.g., simulation of climate-change scenarios); (vi) Water-Energy Nexus Analysis; v) Water Quantity/Quality comparison over time.

\section{Results}

An important part of the analysis involves the classification of stakeholders that are critical to the project and should remain an integral part of it. All relevant stakeholders are mapped and 
classified, while; for each stakeholder category, their expected interest and possible conflicts with other stakeholder groups are presented in Table 1. This analysis provides us with a common basis for the presentation of the Water4Cities platform and the actors' involvements in the two Use Cases.

Table 1. Water4Cities Stakeholders: Main Interests and Conflicts.

\begin{tabular}{|c|c|c|}
\hline Actor Category & $\begin{array}{l}\text { Interest of the Actors with Respect to } \\
\text { Water4Cities }\end{array}$ & Conflicts among Actors \\
\hline $\begin{array}{l}\text { National ministries and } \\
\text { agencies } \\
\text { (for finance, energy, } \\
\text { development, tourism etc.) }\end{array}$ & $\begin{array}{l}\text { Have a strong interest in improving water } \\
\text { management services in the country; } \\
\text { Responsible for policy coordination, guidance } \\
\text { and ensuring that all aspects relevant to } \\
\text { achieving Water4Cities objectives and for } \\
\text { sustaining the improved services to the required } \\
\text { level are dealt with high efficiency }\end{array}$ & $\begin{array}{l}\text { Short term interests (political or } \\
\text { financial gains, meeting coverage } \\
\text { targets etc.) conflicting with long } \\
\text { term interest of sustainability and as } \\
\text { a consequence with NGOs which } \\
\text { fight for this purpose }\end{array}$ \\
\hline $\begin{array}{l}\text { Authorities } \\
\text { (regional, local) }\end{array}$ & $\begin{array}{l}\text { Obtain further information and knowledge that } \\
\text { will guide the implementation of practices } \\
\text { aiming at the sustainable exploitation of water } \\
\text { in line with high consumers' water services in } \\
\text { their respective region the national and the EU } \\
\text { legislative and institutional framework; Reduce } \\
\text { water stresses associated with climate change, } \\
\text { while generating business opportunities for } \\
\text { SMEs }\end{array}$ & $\begin{array}{l}\text { Local authorities' decision -making } \\
\text { water policies may conflict with } \\
\text { neighboring regions under the frame } \\
\text { of competitive water resources } \\
\text { exploitation and/or with national } \\
\text { agencies due to unequal funding } \\
\text { distribution for innovative and } \\
\text { optimized water supply solutions }\end{array}$ \\
\hline $\begin{array}{l}\text { Public/Private utility } \\
\text { companies (water/electricity } \\
\text { suppliers, utility engineers } \\
\text { etc.) }\end{array}$ & $\begin{array}{l}\text { Benefit from lower operating costs, cost-effective } \\
\text { and environmental-friendly practices, and } \\
\text { improvement in their water services overall } \\
\text { regime; } \\
\text { Gain further information and knowledge about } \\
\text { present and future decisions for water } \\
\text { sustainability issues }\end{array}$ & $\begin{array}{l}\text { Private water utilities compete } \\
\text { public in terms of the quality of their } \\
\text { water services and customer's } \\
\text { satisfaction over quantity, quality } \\
\text { and economic status of the supplied } \\
\text { water }\end{array}$ \\
\hline $\begin{array}{l}\text { Private Sector (food/chemical } \\
\text { industries, energy } \\
\text { production/ICT/Urban } \\
\text { planning companies etc.) }\end{array}$ & $\begin{array}{l}\text { High interest among private enterprises which } \\
\text { depend on a reliable supply of good quantity } \\
\text { and quality water in order to operate their } \\
\text { businesses; } \\
\text { High interest for tourist companies in terms of } \\
\text { their customers' satisfaction about water } \\
\text { services; High interest among ICT companies in } \\
\text { providing water regulators with the appropriate } \\
\text { software and hardware and in standardization } \\
\text { of the IoT }\end{array}$ & $\begin{array}{l}\text { Urban water supply interests } \\
\text { competing with other interests } \\
\text { including water for food, industry, } \\
\text { tourism, domestic use, and nature; } \\
\text { Private sector is a high-water } \\
\text { consumer and an important polluter, } \\
\text { so conflicts usually arise with NGOs } \\
\text { and local authorities w.r.t. irrational } \\
\text { water usage and pollution }\end{array}$ \\
\hline $\begin{array}{l}\text { Private Citizens } \\
\text { (Households/domestic use, } \\
\text { land owners) }\end{array}$ & $\begin{array}{l}\text { High interest for households in receiving } \\
\text { adequate supply of piped water to their homes } \\
\text { at a satisfying pressure and at appropriate } \\
\text { drinking quality }\end{array}$ & $\begin{array}{l}\text { Community members find water } \\
\text { expensive and/or of low quality, } \\
\text { which results to them relying on } \\
\text { bottled water. }\end{array}$ \\
\hline $\begin{array}{l}\text { Higher education } \\
\text { representatives (Academia, } \\
\text { Universities and research } \\
\text { centres) }\end{array}$ & $\begin{array}{l}\text { Gain knowledge and deeper insight on issues } \\
\text { related to water sustainability in order to further } \\
\text { promote research and innovation in the } \\
\text { respective scientific fields }\end{array}$ & $\begin{array}{l}\text { Higher education may come in } \\
\text { conflict with national and local } \\
\text { authorities who persist in old } \\
\text { practices }\end{array}$ \\
\hline $\begin{array}{l}\text { NGOs environmental } \\
\text { protection, sustainable } \\
\text { development etc. }\end{array}$ & $\begin{array}{l}\text { NGOs put pressure on local and national } \\
\text { authorities to adopt innovative and } \\
\text { environmental-friendly water management } \\
\text { practices }\end{array}$ & $\begin{array}{l}\text { NGOs come in conflict with local } \\
\text { and national authorities, private } \\
\text { sector and public utility companies } \\
\text { about the consequences of } \\
\text { unsustainable practices }\end{array}$ \\
\hline $\begin{array}{l}\text { Stakeholders' } \\
\text { associations/chambers } \\
\text { Professional, Tourist, Water } \\
\text { consumer's associations. }\end{array}$ & $\begin{array}{l}\text { Obtain knowledge and increasing awareness } \\
\text { concerning the protection and sustainable } \\
\text { exploitation of water resources while exploring } \\
\text { the potential of innovative ICT water } \\
\text { management approaches in delivering high } \\
\text { water services. }\end{array}$ & $\begin{array}{l}\text { Stakeholders' associations are in } \\
\text { conflict with local and national } \\
\text { authorities, private and public } \\
\text { companies when legislations and } \\
\text { practices are in contrast with their } \\
\text { interests }\end{array}$ \\
\hline
\end{tabular}




\section{Discussion}

The relevance of stakeholder mapping is established through the project case studies. Each case study has a different focus and faces different environmental and/or anthropogenic pressures. The diversity of the case studies ensures that the Water4Cities solution is not designed for a specific system but can be implemented in a wide range of urban environments, thus making it widely applicable.

\subsection{Greek Case Study: Water Demand Management}

The Greek demonstration site is located in Skiathos Island, which belongs to the complex of Sporades at the Aegean Sea and the prefecture of Thessaly. Skiathos is a small hilly town of 5000 inhabitants. Main economic activities of Skiathos society are tourism and agriculture. Skiathos water supply is served by groundwater, drilled by a main drilling (Figure 2). Recently, more drillings, 5 at total, have been added to reinforce water supply. Water demand in the island depicts high seasonal variability. Past research has shown that its intense seasonality is thoroughly linked to weather variables-namely, mean temperature, high temperature, precipitation and wind speed-and demographic variables, most importantly the touristic activity $[15,16]$. Taking into account that gross water withdrawals also include non-revenue water, water resources demand is also proven to be linked, through leakage, to technical characteristics of the network such as bursts, age of the network, number of customer connections, length of network, pressure in the network, etc. [17]. In the context of the Greek pilot, the Water4Cities will be interconnected with the existing software tools, designed and customized for Skiathos WDN supported by the EU funded FP7 project ISS-EWATUS [18]. ISSEWATUS spatio-temporal tool [19] enables surveillance and operation of the WDN depicting some subroutines (a) all water meters mapped, (b) access to water meter profile, (c) access household historical data and (d) assess of optimal pressure PRV profile based on the water demand forecast. In this line, the Water4Cities will be interconnected with the existing ISS-EWATUS tools used for water monitoring to provide added value capabilities to the current tools, by developing new decision support services for supporting a holistic approach on decreasing water needs (leakage, demand, pressure driven demand and energy) and providing an integrated scheme of monitoring and controlling water supply in terms of quantity and quality.

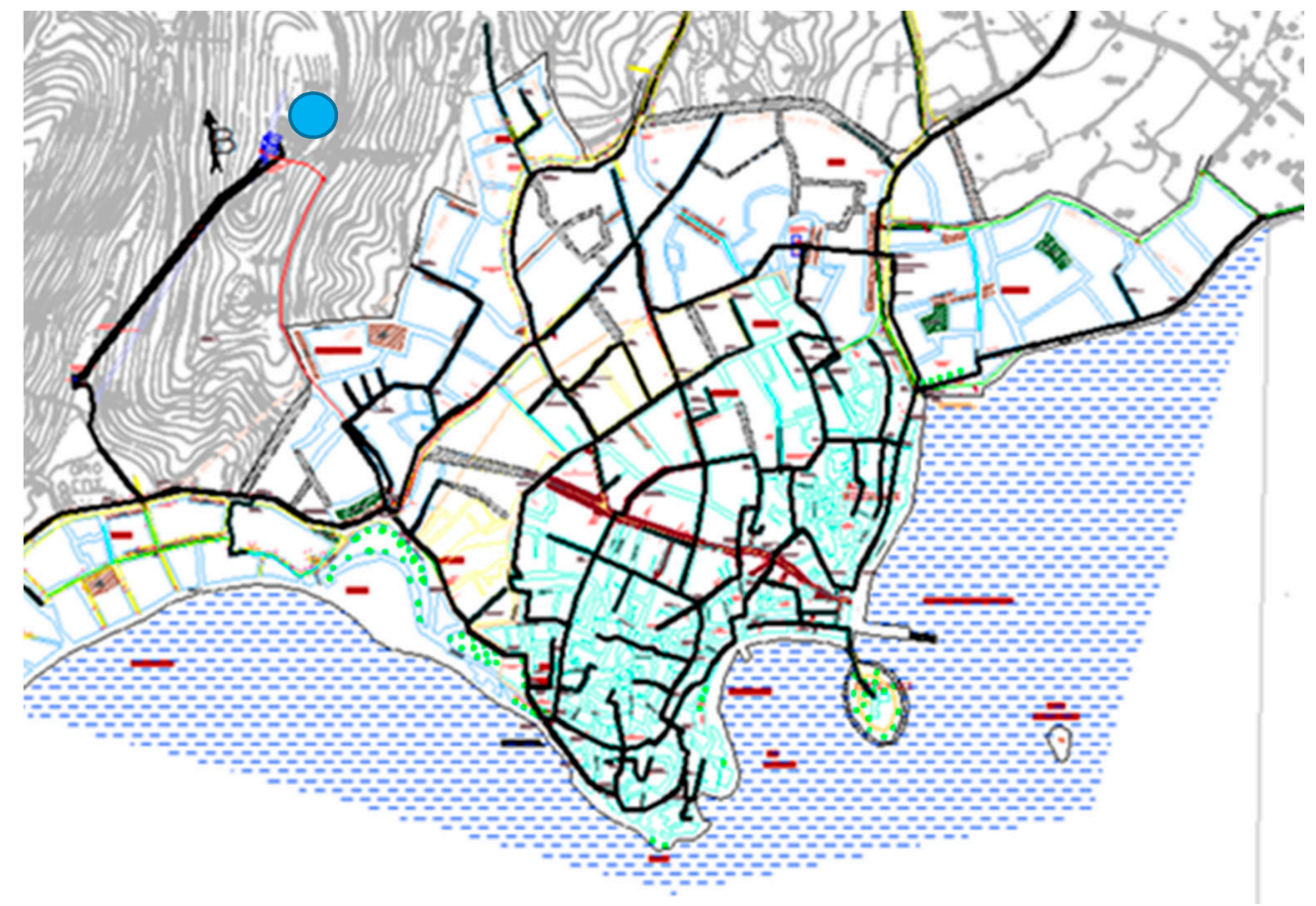

Figure 2. Skiathos W.D.N. denoted in black with its main drilling denoted in blue. 


\subsection{Slovenian Pilot-Water Reuse ENBS Planning}

The Slovenian case study will focus on the Ljubljana Urban Region (LUR), the central region of Slovenia with Ljubljana, the capital of Slovenia (Figure 3). The urban area of the Ljubljana City spreads between two main rivers - the Ljubljanica River and the Sava River, which is the main Slovenian river. The urban and agricultural area between the two rivers is a living and working place for almost 500,000 Slovenian inhabitants. LUR has a long history of various flood protection measures due to its vulnerability to flooding. Despite these measures, many parts of the urban area of the City of Ljubljana are still heavily threatened by the floods, due to intensive urbanization, surface run-off increase as well as climate change effects.

The Slovenian use case will rely on existing platforms based on NUKLEUS tool developed by LUZ, incorporating modelling and monitoring data of the LUR, such as Rivers Data (location, Flow Rate, Water Level), Soil Data, Underground Water Level Data, Slope Data, Data of urban water distribution systems - water utility networks (Capacity, Age, Location), Meteorological Data, Urban Land Use Data (current, predicted). Some of the developed platforms are open to public and some are used only by municipality of Ljubljana and their public utility companies. In the context of the Slovenian pilot, the Water4Cities will be interconnected with the existing Nukleus GIS systems used for water monitoring and urban planning. In this line, Water4Cities will provide added value capabilities to the current tools, by developing new decision support services for the identification and analysis of possible NBSs and related costs and benefits, the maintenance of water infrastructure and the empowerment of citizens through crowdsourcing capabilities.

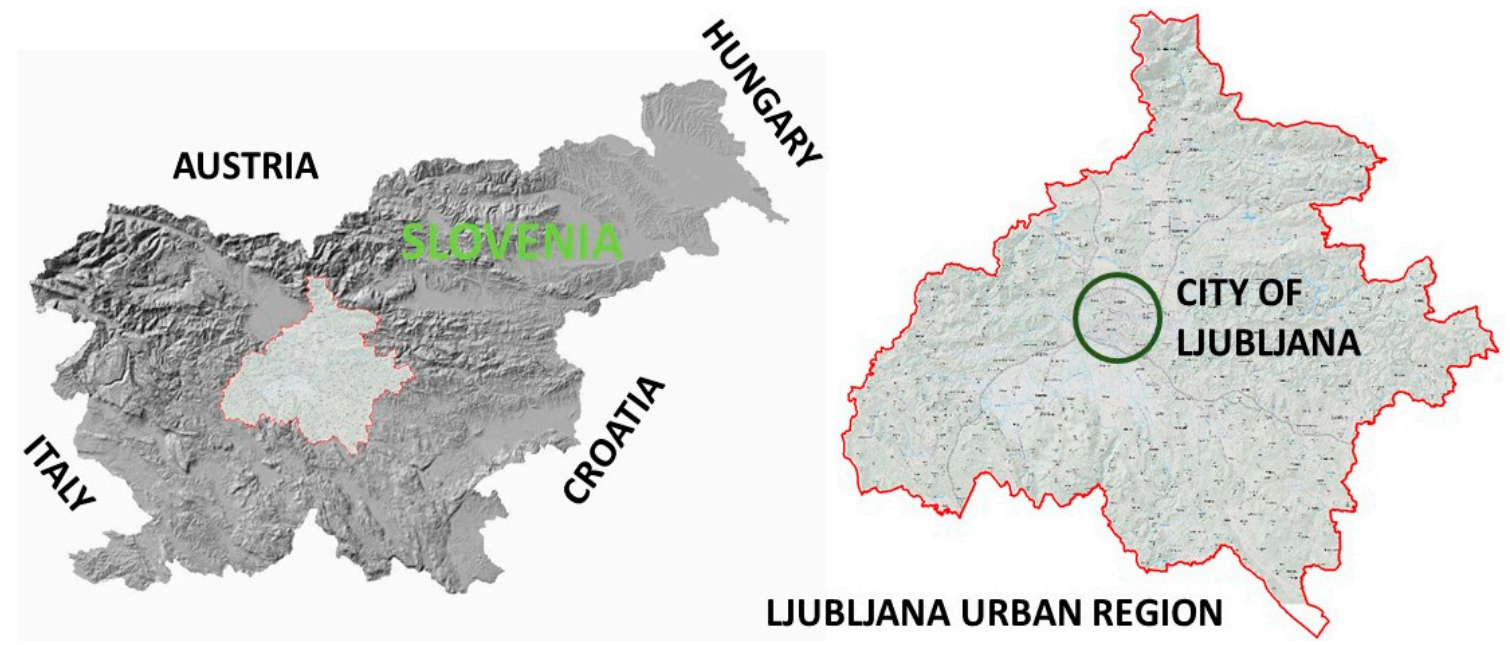

Figure 3. Ljubljana Use Case Area.

\section{Conclusions}

Despite, the ongoing research work in the area of smart water management, the deployment of advanced high-quality real-time water monitoring tools and services in urban settings is still far from being achieved due to several reasons including difficulties in collecting precise monitoring data, lack of interoperability standards and use of simple data mining and data visualization techniques that do not fully exploit the data value. As a response to this challenge, in this paper, the Water4Cities approach is presented, encompassing the high-level system architecture and the target pilot case studies. The Water4Cities approach aims to develop novel, beyond state-of-the-art mechanisms for water sensor data collection as well as sophisticated data mining algorithms and data visualization techniques to support two real use cases focusing on water demand management and water reuse and urban planning. The implementation of the platform and the pilot demonstrators is currently work in progress by the Water4Cities consortium partners. 
Author Contributions: S.R. has coordinated the collection of inputs from project partners and led the paper writing. D.K. and A.S. have contributed in the positioning of the project with respect to existing water management solutions and assisted in the design of the pilot cases. K.K. (Klemen Kenda) and M.S. contributed in the design of the high-level architecture with respect to the data analytics part. P.R. contributed in the design of the system and applications with respect to the data visualization part. J.V. contributed in the design of the data collection part through the IoT gateway. N.M. is responsible for the Greek pilot and P.P. is responsible for the Slovenian pilot design. K.K. (Kostas Kalaboukas) provided feedback and comments on the system design. Finally, C.L., the scientific coordinator of the Water4Cities project contributed in the quality assurance throughout the design of the decision support system and pilot studies and reviewed the paper.

Acknowledgments: The work described in this paper has been conducted within the project Water4Cities. This project has received funding from the European Union's Horizon 2020 Research and Innovation Staff Exchange programme under grant agreement number 734409. This paper and the content included in it do not represent the opinion of the European Union, and the European Union is not responsible for any use that might be made of its content.

Conflicts of Interest: The authors declare no conflict of interest.

\section{References}

1. Vörösmarty, C.J.; Green, P.; Salisbury, J.; Lammers, R.B. Global water resources: Vulnerability from climate change and population growth. Science 2000, 289, 284-288, doi:10.1126/science.

2. Moe, C.L.; Rheingans, R.D. Global challenges in water, sanitation and health. J. Water Health 2006, 4, 41-57, doi:10.2166/wh.2006.0043.

3. Mala-Jetmarova, H.; Sultanova, N.; Savic, D. Lost in Optimisation of Water Distribution Systems? A Literature Review of System Design. Water 2018, 10, 307, doi:10.3390/w10030307.

4. Laspidou, C.S. ICT and stakeholder participation for improved urban water management in the cities of the future. Water Util. J. 2014, 8, 79-85.

5. Trenberth, K.E. Changes in precipitation with climate change. Clim. Res. 2011, 47, 123-138, doi:10.3354/cr00953.

6. Batchelor, C. Improving water use efficiency as part of integrated catchment management. Agric. Water Manag. 1999, 40, 249-263, doi:10.1016/S0378-3774(98)00125-5.

7. Glasgow, H.B.; Burkholder, J.M.; Reed, R.E.; Lewitus, A.J.; Kleinman, J.E. Real-time remote monitoring of water quality: A review of current applications, and advancements in sensor, telemetry, and computing technologies. J. Exp. Mar. Biol. Ecol. 2004, 300, 409-448, doi:10.1016/j.jembe.2004.02.022.

8. Directive, W.F. Water Framework Directive; Common Implementation: Brussels, Belgium, 2000.

9. Water Management Plans and Best Practices at EPA. Available online: https://www.epa.gov/greeningepa/ water-management-plans-and-best-practices-epa (accessed on 10 April 2018).

10. Romer, K.; Mattern, F. The design space of wireless sensor networks. IEEE Wirel. Commun. 2004, 11, 54-61, doi:10.1109/MWC.2004.1368897.

11. Merrill, W.M.; Newberg, F.; Sohrabi, K.; Kaiser, W.; Pottie, G. Collaborative networking requirements for unattended ground sensor systems. In Proceedings of the 2003 IEEE Aerospace Conference, Big Sky, MT, USA, 8-15 March 2003.

12. Ler, L.G. Analysis of Current ICT Solutions in Water Business Processes. Procedia Eng. 2016, 154, 3-10, doi:10.1016/j.proeng.2016.07.410.

13. Vahala, R. European Vision for Water Supply and Sanitation in 2030. In Water Supply and Sanitation Technology Platform; WHO: Geneva, Switzerland, 2000.

14. Water4Cities. Available online: http://www.water4cities.eu/ (accessed on 10 March 2018).

15. Kofinas, D.; Mellios, N.; Papageorgiou, E.; Laspidou, C. Urban water demand forecasting for the island of Skiathos. Procedia Eng 2014, 89, 1023-1030, doi:10.1016/j.proeng.2014.11.220.

16. Mellios, N.; Kofinas, D.; Papageorgiou, E.; Laspidou, C. A multivariate analysis of the daily water demand of Skiathos Island, Greece, implementing the artificial neuro-fuzzy inference system (ANFIS). In Proceedings of the 36th IAHR World Congress, Delft, The Netherlands, 28 June-3 July 2015.

17. Kofinas, D.; Papageorgiou, E.; Laspidou, C.; Mellios, N.; Kokkinos, K. Daily multivariate forecasting of water demand in a touristic island with the use of artificial neural network and adaptive neuro-fuzzy inference system. In Proceedings of the 2016 IEEE International Workshop on Cyber-physical Systems for Smart Water Networks (CySWater), Vienna, Austria, 11-16 April 2016; pp. 37-42. 
18. ISS-EWATUS. Available online: http://issewatus.eu/ (accessed on 27 March 2018).

19. ISS-EWATUS DSS. Available online: http://www.issewatus.certh.gr/ (accessed on 27 March 2018).

(C) 2018 by the authors. Licensee MDPI, Basel, Switzerland. This article is an open access article distributed under the terms and conditions of the Creative Commons Attribution (CC BY) license (http://creativecommons.org/licenses/by/4.0/). 